\title{
Denitrification and oxygen consumption in sediments of two south Texas estuaries
}

\author{
Won Bae Yoon, Ronald Benner* \\ Marine Science Institute, University of Texas at Austin, Port Aransas, Texas 78373, USA
}

\begin{abstract}
Spatial and temporal variations in rates of denitrification and oxygen consumption were measured in sediments of the Nueces and Guadalupe Estuaries in southern Texas, USA. Denitrification rates varied from 4.0 to $71.1 \mu \mathrm{mol} \mathrm{N} \mathrm{m}^{-2} \mathrm{~h}^{-1}$ in the Nueces Estuary and from 4.6 to $34.7 \mu \mathrm{mol} \mathrm{N} \mathrm{m}^{-2} \mathrm{~h}^{-1}$ in the Guadalupe Estuary. Denitrification accounted for 29 to $80 \%$ of total benthic $\mathrm{N}$ flux in the study areas. Oxygen consumption rates ranged from 176 to $818 \mu \mathrm{mol} \mathrm{O}_{2} \mathrm{~m}^{-2} \mathrm{~h}^{-1}$ in Nueces Estuary and from 208 to $550 \mu \mathrm{mol} \mathrm{O}_{2} \mathrm{~m}^{-2} \mathrm{~h}^{-1}$ in Guadalupe Estuary. In both estuaries denitrification and oxygen consumption rates were generally higher in the upper estuaries where the porosity and organic matter contents of sediments were typically highest. Among 3 measurements in different seasons, the lowest denitrification and oxygen consumption rates were usually observed during winter. Chemical oxygen consumption, as measured using formalin-killed controls, was about $50 \%$ of the total oxygen consumption. A considerable portion (ca $50 \%$ ) of biological oxygen consumption was attributed to nitrification in sediments. We estimated that carbon mineralization by denitrifiers was as much as 40 to $179 \%$ of that by aerobic heterotrophs. In the Guadalupe Estuary, denitrification removed about $38 \%$ of the measured inputs of organic and inorganic nitrogen. In the Nueces Estuary, the amount of nitrogen removed by denitrification was ca 2 times greater than the measured nitrogen inputs from the Nueces River and precipitation, suggesting that unmeasured anthropogenic inputs along the perimeter of the estuary were very important for maintaining nitrogen balance.
\end{abstract}

\section{INTRODUCTION}

Estuaries are often sites of high productivity due in large part to the input of terrestrially derived nutrients (see Deegan et al. 1986 and references therein). Of these nutrients, nitrogen is of primary importance for maintaining high productivity, and thus the transformations and fates of nitrogenous compounds are of great interest. There are 4 potentially major pathways for the removal of fixed nitrogen from biological cycling in estuaries: (1) transport to coastal waters, (2) removal by fisheries activity, (3) burial in sediments, (4) loss as dinitrogen gas $\left(\mathrm{N}_{2}\right)$ resulting from denitrification.

There have been few studies comparing the relative importance of these removal processes, but measurements of denitrification rates alone indicate that a major fraction of the fixed nitrogen entering estuaries is remineralized to $\mathrm{N}_{2}$ during denitrification (Seitzinger 1988). In some cases, denitrification may indirectly control coastal primary productivity (Nixon 1981).

'Addressee for correspondence
In Norsminde Fjord (Denmark), about $25 \%$ of the external nitrate input is removed by denitrification (Jørgensen \& Sørensen 1988). Smith et al. (1985) reported that about $50 \%$ of the riverine nitrate entering Four League Bay (Louisiana, USA) was removed by denitrification, and in Ochlockonee Bay (Florida, USA), about $54 \%$ of the riverine input of dissolved inorganic nitrogen is removed by denitrification (Seitzinger 1987). These studies have clearly established that denitrification is a major sink for $\mathrm{N}$ in estuaries.

The role of denitrification in carbon mineralization in sediments is not well documented. Sulfate reduction is typically the dominant pathway for organic matter oxidation in shallow coastal marine sediments (Jørgensen 1977). In addition to sulfate reduction, aerobic respiration can also be a major pathway of carbon mineralization in sediments (Sørensen et al. 1979). Given the major role denitrification has in nitrogen mineralization in estuaries it is likely to be an important pathway for carbon mineralization as well.

In this study, we present data on the spatial and temporal variations in rates of denitrification and 
oxygen consumption in sediments from the Nueces and Guadalupe Estuaries on the south Texas Gulf coast of the USA. These 2 estuaries are similar in size, but freshwater inflow to Guadalupe Estuary is about 5 times greater than to Nueces Estuary (TDWR 1980, 1981). The quantitative significance of denitrification to nitrogen and carbon cycling is addressed, and the relative contributions of biological and chemical processes to total oxygen consumption in sediments are investigated.

\section{METHODS}

Study areas. Sediment cores were collected from 2 south Texas estuaries, the Nueces Estuary and the Guadalupe Estuary. In Nueces Estuary 2 stations (Stns A and B) were in Nueces Bay which adjoins with the Nueces River, and 2 stations (Stns $C$ and $D$ ) were in Corpus Christi Bay (Fig. 1). There is a major city (Corpus Christi) and industrial complex along the southwest shore of the Nueces Estuary. The Nueces River is usually the main source of freshwater inflow into Nueces Estuary, although municipal and industrial inputs may exceed direct riverine input in drier years. There is no major city directly adjacent to the Guadalupe Estuary. The San Antonio and Guadalupe Rivers provide the major freshwater input into the Guadalupe Estuary. All stations (A, B and C) in Guadalupe Estuary were located in San Antonio Bay (Fig. 1). Samples from the Nueces Estuary were collected in
August 1988, January and May 1989, and samples from the Guadalupe Estuary were collected in October 1988, January and May 1989. This was a relatively dry period in southern Texas.

Sediment collection and incubation. Sediment cores (7.6 cm i.d., $25 \mathrm{~cm}$ deep) were collected using SCUBA or a hand-operated coring device from a boat. Cores were immediately transported to the laboratory in Port Aransas and transferred to glass incubation chambers of the same inner diameter within $24 \mathrm{~h}$ of collection. Chambers were fabricated at the University of Texas and had 2 sampling ports which were sealed with butyl rubber stoppers and screw caps with $9 \mathrm{~mm}$ openings (Bellco Glass Inc.). A gas sampling port was located near the top of the chamber, and a water sampling port was located just above the sediment-water interface in the chamber. The volume of the water phase was 180 to $190 \mathrm{ml}$ and the volume of the gas phase was 60 to $70 \mathrm{ml}$. The depth of sediments in the chamber was approximately $7 \mathrm{~cm}$. The bottom of the chamber was sealed with a butyl rubber stopper held in place with a plexiglass frame

After sealing the sampling ports with butyl rubber stoppers, the water and gas phases of each chamber were flushed with a $\mathrm{N}_{2}$-free gas mixture $(80 \% \mathrm{He}$ and $20 \% \mathrm{O}_{2}$ ) for $1 \mathrm{~h}$ through the sampling ports using syringe needles. During the initial 9 to $12 \mathrm{~d}$ of incubation the chambers were purged for $1 \mathrm{~h}$ each day.

Three replicate cores were collected from each station and transferred to incubation chambers. One of the cores was utilized as a control to monitor for

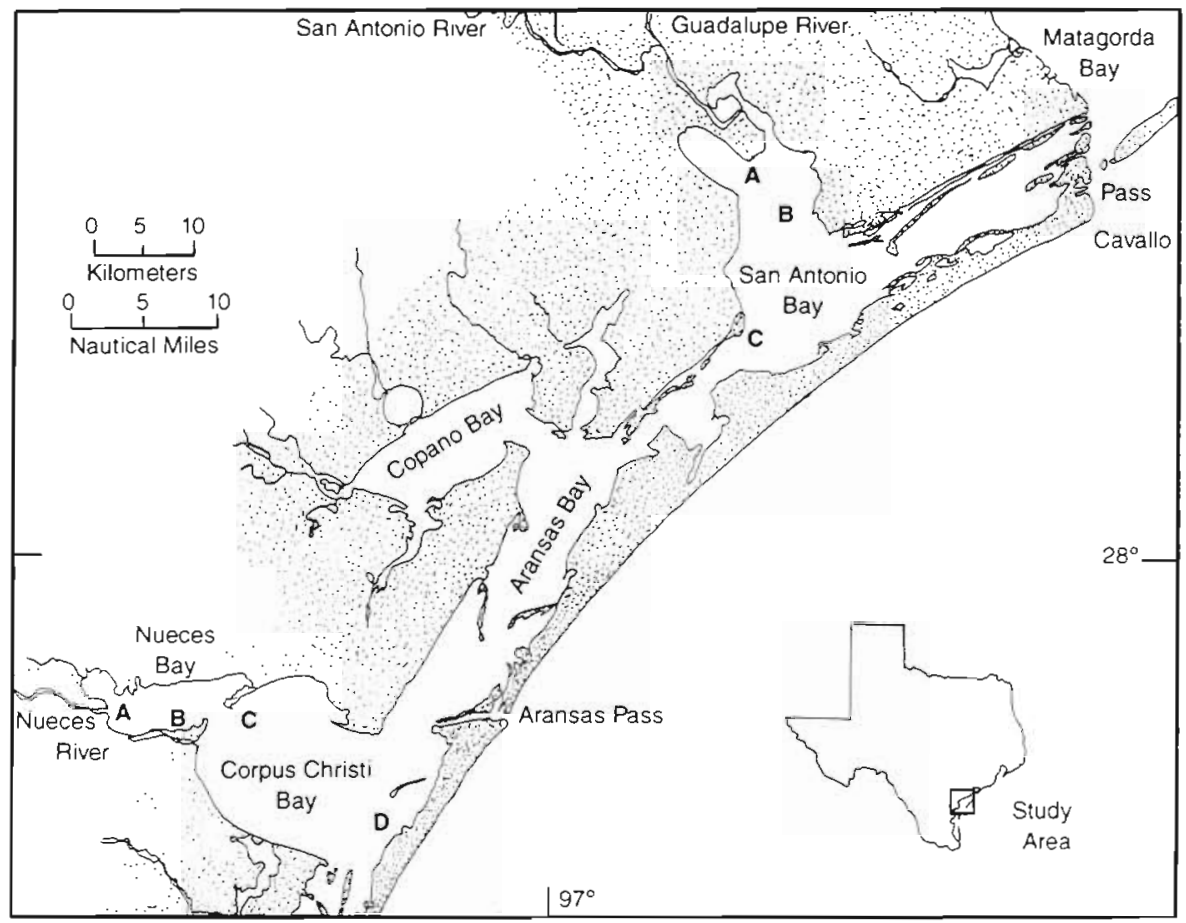

Fig. 1 Location of the sampling sites in Nueces Estuary (Stns $A$ and $B$ in Nueces Bay and Stns C and D in Corpus Christi Bay) and in Guadalupe Estuary (Stns A, B and $C$ in San Antonio Bayl 
background $\mathrm{N}_{2}$ inputs and chemical oxygen consumption. Controls received $10 \mathrm{ml}$ of formalin $37 \%$ formaldehyde) that was added to the water phase of the chamber. Anaerobic controls (flushed with $\mathrm{He}$ ) were used to investigate the coupling between nitrification and denitrification during August 1988 in Nueces Estuary sediments.

Chambers were incubated in the dark at in situ temperatures in a water bath. After an initial equilibration period of about $10 \mathrm{~d}$, the chambers were sampled at 1 to $3 \mathrm{~d}$ intervals for $\mathrm{N}_{2}$ production and $\mathrm{O}_{2}$ consumption. During each incubation period, chambers were shaken $(70 \mathrm{rpm})$ for $1 \mathrm{~h}$ every day. No differences in rates of denitrification and oxygen consumption were observed between samples that were shaken continuously and samples that were shaken intermittently as described above. Sediments in the chambers were not disturbed during shaking. Chambers were also shaken for $1 \mathrm{~h}$ immediately before gas sampling to equilibrate the gas phase with the water phase.

Before sampling from the gas phase of the chamber, a gas-tight syringe $(250 \mu \mathrm{l})$ was flushed 6 times with helium. After flushing, the syringe was filled with helium which was then ejected to the air to prevent contamination with atmospheric $\mathrm{N}_{2}$ while the syringe needle was inserted into the gas sampling port on the chamber. The gas sampling port of the chamber was also flushed vigorously with helium to reduce the possibility of $\mathrm{N}_{2}$ contamination during sampling. In order to prevent contamination of the gas sample in the syringe with atmospheric $\mathrm{N}_{2}$ before injection into the gas chromatograph, a $200 \mu \mathrm{l}$ sample was taken and $100 \mu \mathrm{l}$ of the sample was ejected to the air during transfer to the injection port of the gas chromatograph. The injection port was also flushed vigorously with helium. Using the above procedure, we could not detect any contamination by atmospheric $\mathrm{N}_{2}$ during sampling. After gas sampling, water was sampled from chambers for measurement of ammonium and nitrate plus nitrite concentrations. Chamber water was then replaced with water collected from the sampling site, and the next incubation cycle was started repeating the previous procedure. Measurements of $\mathrm{N}_{2}$ production and $\mathrm{O}_{2}$ consumption were made repeatedly for 4 to 5 incubation cycles for each core.

To check for contamination with atmospheric $\mathrm{N}_{2}$ during incubation, distilled water or seawater was poisoned with formalin ( $3 \%$ final concentration) and added to the chambers until the volume of the gas phase was the same as in chambers with sediments. After the water and gas phases were flushed with a helium and oxygen gas mixture, the chambers were incubated in the water bath in the dark as described previously. Gas samples were analyzed daily over a $4 \mathrm{~d}$ incubation period.
Analytical measurements. Gas samples $(100 \mu \mathrm{l})$ were analyzed for $\mathrm{N}_{2}$ and $\mathrm{O}_{2}$ using a gas chromatograph (Carle Instruments Inc., Model 8500) equipped with a thermal conductivity detector. Gases were separated using a stainless steel column $(3 \mathrm{~m} \times 3 \mathrm{~mm})$ packed with molecular sieve 5A (70/80 mesh size) and helium as the carrier gas $\left(20 \mathrm{ml} \mathrm{min}^{-1}\right)$. The concentrations of $\mathrm{N}_{2}$ and $\mathrm{O}_{2}$ were calculated from peak areas using a Shimadzu CR4A integrator. Denitrification rates were calculated by subtracting the $\mathrm{N}_{2}$ concentration in the killed control chamber from that in the replicate live chambers.

Fluxes of ammonium and nitrate plus nitrite from sediments to the overlying water were determined in October 1988 and May 1989 from measurements of net increases in the concentrations of these nutrients. Parallel incubations with water only were used to measure the net changes in nutrient concentrations in the water column. Colorimetric methods were used for determination of ammonium (Solorzano 1969) and nitrate concentrations (Strickland \& Parson 1972) using either a spectrophotometer (Beckmann Model 24) or autoanalyzer (Technicon II).

\section{RESULTS}

\section{Sediment characteristics}

Redox potentials ( $\mathrm{mV}$ ) of surface sediments usually showed positive values throughout the study period, and negative values began to appear 2 to $4 \mathrm{~cm}$ below the sediment-water interface (Table 1a). During winter (January), redox potentials of sediments were higher compared to other seasons, presumably because of reduced levels of microbial activity. We observed negative values of redox potentials even in surface sediments at Stn D in Nueces Estuary during the summer. We also observed that bottom waters at Stn D had low concentrations of dissolved oxygen during that period. Sediments from Stn D had positive redox potentials at every depth, however, during the winter and spring.

Sediments from the lower estuary stations had lower percentages of organic matter in both Nueces and Guadalupe Estuaries (Table 1b). Sediments from Stn B in Guadalupe Estuary had the highest content of organic matter (14 to $15 \mathrm{wt} \%$ ) of all study sites. Sediments at all stations were muddy, except Stn D of Nueces Estuary where sediments contained fine sand. Sediments at Stn D had the lowest amount of organic matter ( 2 to $4 \mathrm{wt} \%$ ) among the 2 estuaries.

The top $10 \mathrm{~cm}$ of sediments at Stn A in Nueces Estuary were very soft and had the highest content of water $(85 \% \mathrm{v} / \mathrm{v})$, while the sediments of Stn D had the lowest water content ( $53 \%$ ) among all stations in the study areas (Table 1c). 


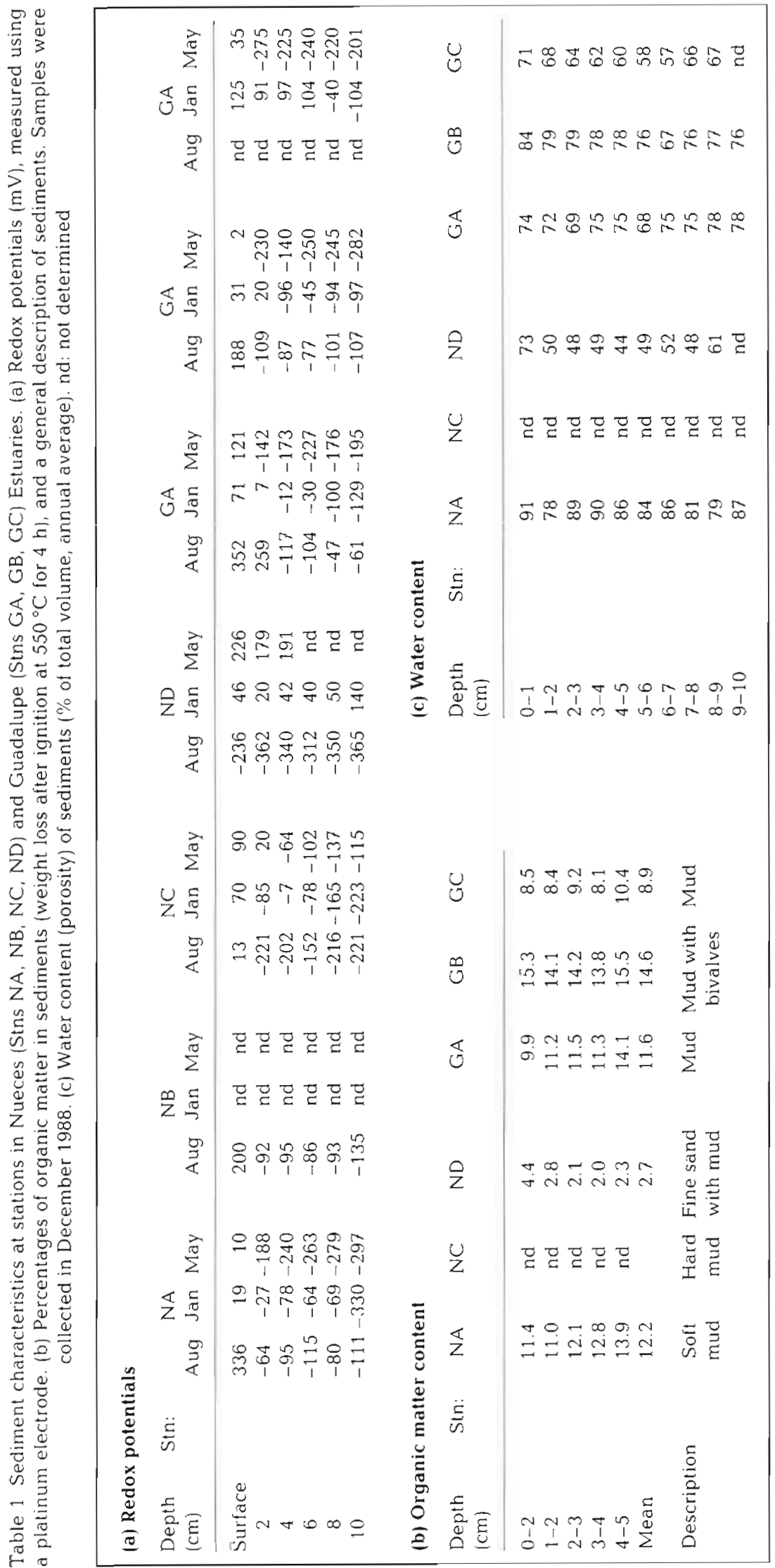

\section{Denitrification rates}

Fluxes of $\mathrm{N}_{2}$ from sediments declined rapidly during the first $9 \mathrm{~d}$ of incubation (data not shown). Higher fluxes of $\mathrm{N}_{2}$ during the initial incubation period were probably due to the flux of $\mathrm{N}_{2}$ that was initially dissolved in sediment pore waters. These results are similar to those observed by Seitzinger et al. (1980), who recommended that denitrification rate measurements be made after an initial $10 \mathrm{~d}$ degassing period. In the present study, denitrification rates were measured after the first 9 or $10 \mathrm{~d}$ of incubation. After this initial degassing period, increases in $\mathrm{N}_{2}$ were linear during each incubation period in both live and control chambers (Fig. 2).

We were interested in determining whether the flux of $\mathrm{N}_{2}$ measured after $10 \mathrm{~d}$ in killed controls resulted from continued pore water exchange or if atmospheric nitrogen was entering the chambers during incubation. To test for these possibilities, chambers were incubated with formalin-killed water samples. A steady flux of $36.3 \pm 1.5 \mu \mathrm{mol} \mathrm{N} \mathrm{m}^{-2} \mathrm{~h}^{-1}(\mathrm{n}=8)$ was measured in all control chambers. These rates of $\mathrm{N}_{2}$ flux were similar to the rates ( 30 to $40 \mu \mathrm{mol} \mathrm{m}^{-2} \mathrm{~h}^{-1}$ ) measured in killed-control chambers with sediments, indicating that gas fluxes after 9 or $10 \mathrm{~d}$ of incubation result primarily from the diffusion of atmospheric nitrogen during incubation rather than exchange of pore-water nitrogen. The rates of atmospheric diffusion into our chambers were much higher than those measured previously in chambers sealed with a rubber o-ring and held together with a metal clamp (Seitzinger et al. 1980. Gardner et al. 1987).

We also found that there was no significant difference $(p>0.1, n=36)$ between fluxes of $\mathrm{N}_{2}$ in aerobic formalin-killed controls and controls that were incubated anaerobically to terminate nitrification. The absence of measurable denitrification in anaerobic controls indicates that a tight 


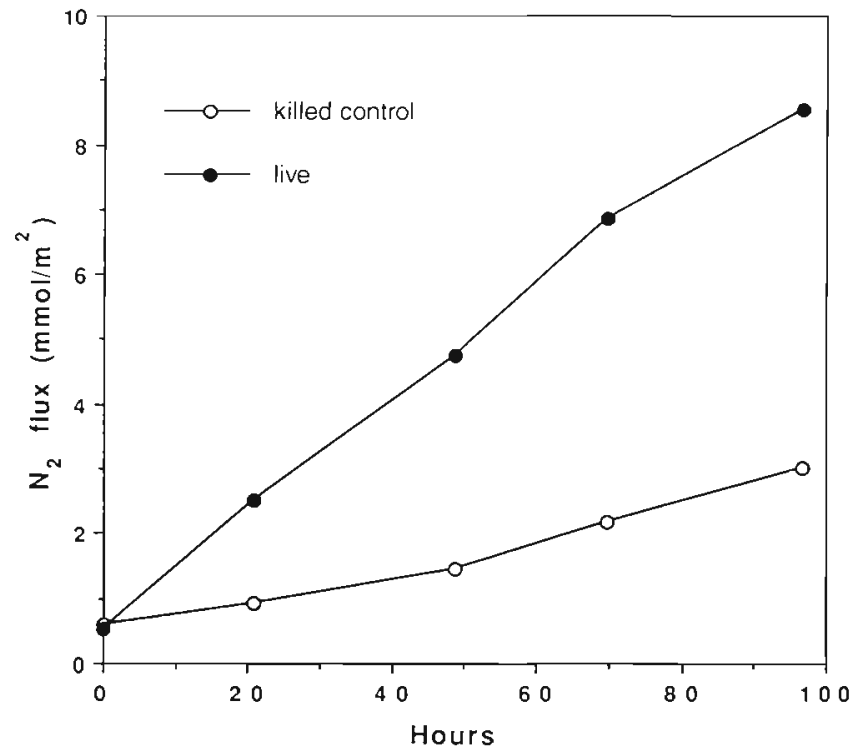

Fig. 2. Fluxes of $\mathrm{N}_{2}$ gas in chambers containing live and formalin-killed sediment cores. Cores were incubated for $10 \mathrm{~d}$ prior to these measurements to allow degassing of pore-water

$\mathrm{N}_{2}$ and penetration of formalin throughout sediments

coupling exists between nitrification and denitrification in these sediments. Formalin-killed controls were run at all stations for each sampling period, and $\mathrm{N}_{2}$ fluxes measured in controls were subtracted from rates measured in replicate live chambers. Formalin-killed controls were preferred over anaerobic controls because they could also be used to distinguish chemical. from biological oxygen consumption.

Salinities ranged from 32 to $44 \%$ in Nueces Estuary and 11 to $29 \%$ in Guadalupe Estuary during the study period. Salinity ranges in the 2 estuaries reflect differences in freshwater inflow. The average freshwater inflow (the mean of $35 \mathrm{yr}$ ) is $1.6 \times 10^{6} \mathrm{~m}^{3} \mathrm{~d}^{-1}$ in Nueces Estuary (TDWR 1981) and $6.1 \times 10^{6} \mathrm{~m}^{3} \mathrm{~d}^{-1}$ in Guadalupe Estuary (TDWR 1980). Salinity appeared to have little direct effect on denitrification, as rates were similar in the 2 estuaries. Denitrification rates ranged from 4.0 to $71.1 \mu \mathrm{mol} \mathrm{m} \mathrm{m}^{-2} \mathrm{~h}^{-1}$ in Nueces Estuary and from 4.6 to $34.7 \mu \mathrm{mol} \mathrm{m} \mathrm{m}^{-2} \mathrm{~h}^{-1}$ in Guadalupe Estuary (Table 2). In general, upper estuary stations exhibited higher denitrification rates than lower estuary stations. The highest denitrification rate was found at Stn $\mathrm{A}$ in Nueces Estuary during summer, and the lowest rate was found at Stn D in Nueces Estuary during winter.

\section{Oxygen consumption rates}

Rates of oxygen consumption (chemical plus biological) in Nueces Estuary sediments ranged from 176 to $409 \mu \mathrm{mol} \mathrm{m}{ }^{-2} \mathrm{~h}^{-1}$ with the exception of a relatively high rate $\left(818 \mu \mathrm{mol} \mathrm{m} \mathrm{m}^{-2} \mathrm{~h}^{-1}\right)$ at $\mathrm{Stn} \mathrm{D}$ in the summer (Table 2). As mentioned earlier, the bottom water of Stn D had low dissolved oxygen concentrations

Table 2. Rates of denitrification and oxygen consumption in Nueces and Guadalupe Estuaries. Incubation temperatures were $30^{\circ} \mathrm{C}$ in August, $16^{\circ} \mathrm{C}$ in January, $24^{\circ} \mathrm{C}$ in October and $23^{\circ} \mathrm{C}$ in May. The averages and standard deviations (SD) of 5 measurements in replicate cores are shown. Control (anaerobic or formalin-killed) values were subtracted from measurements in replicate cores for estimates of $\mathrm{N}_{2}$ production

\begin{tabular}{|c|c|c|c|c|c|c|}
\hline Stn & Month & $\begin{array}{l}\text { Salinity } \\
(\mathrm{ppt})\end{array}$ & $\begin{array}{l}\mathrm{N}_{2} \text { production } \\
\left(\mu \mathrm{mol} \mathrm{m}^{-2} \mathrm{~h}^{-1}\right)\end{array}$ & $\mathrm{SD}$ & $\begin{array}{l}\mathrm{O}_{2} \text { consumption } \\
\left(\mu \mathrm{mol} \mathrm{m} \mathrm{m}^{-2} \mathrm{~h}^{-1}\right)\end{array}$ & $\mathrm{SD}$ \\
\hline \multirow[t]{3}{*}{ NA } & Aug & 38 & 71.1 & 10.6 & 395 & 176 \\
\hline & Jan & 35 & 11.7 & 7.9 & 230 & 77 \\
\hline & May & 37 & 61.5 & 43.7 & 409 & 116 \\
\hline NB & Aug & 36 & 50.7 & 3.8 & 264 & 158 \\
\hline \multirow[t]{3}{*}{$\mathrm{NC}$} & Aug & 36 & 53.9 & 11.9 & 250 & 182 \\
\hline & Jan & 33 & 11.3 & 3.5 & 186 & 73 \\
\hline & May & 32 & 17.6 & 7.5 & 197 & 26 \\
\hline \multirow[t]{3}{*}{ ND } & Aug & 44 & 43.1 & 12.1 & 818 & 40 \\
\hline & $\operatorname{Jan}$ & 33 & 4.0 & 0.5 & 177 & 86 \\
\hline & May & 35 & 8.6 & 2.2 & 176 & 70 \\
\hline \multirow[t]{3}{*}{ GA } & Oct & 15 & 30.3 & 5.8 & 550 & 105 \\
\hline & Jan & 22 & 22.5 & 10.5 & 283 & 46 \\
\hline & May & 11 & 14.2 & 5.9 & 487 & 258 \\
\hline \multirow[t]{2}{*}{$\mathrm{GB}$} & Jan & 19 & 15.4 & 9.1 & 211 & 68 \\
\hline & May & 21 & 34.7 & 5.7 & 485 & 177 \\
\hline \multirow[t]{3}{*}{$\mathrm{GC}$} & Oct & 29 & 16.8 & 9.2 & 416 & 72 \\
\hline & Jan & 23 & 4.6 & 4.7 & 208 & 78 \\
\hline & May & 25 & 21.1 & 12.8 & 423 & 243 \\
\hline
\end{tabular}


when the sediments were collected, and the redox potential of surface sediments was $-236 \mathrm{mV}$ (Table 1) indicating very reducing conditions. Therefore, the rate we measured under relatively high dissolved oxygen concentrations was probably the potential rate rather than the actual rate. The range of oxygen consumption rates in Guadalupe Estuary (208 to $550 \mu \mathrm{mol} \mathrm{m}^{-2} \mathrm{~h}^{-1}$ ) was similar to that observed in Nueces Estuary. Oxygen consumption rates at the upper estuary stations were generally higher than those at the lower estuary stations for both Nueces and Guadalupe Estuaries as was observed for denitrification rates.

We consistently observed that oxygen was continuously consumed in the killed controls after $9 \mathrm{~d}$ of incubation. As demonstrated earlier, this period of time was sufficient to exchange all of the pore-water $\mathrm{N}_{2}$ and should, therefore, have also been sufficient to mix formalin throughout the sediments. Oxygen consumption in killed controls was most likely due to chemical oxidation of reduced inorganic compounds resulting from anaerobic biological processes, such as sulfate reduction. The addition of formalin to sediments should terminate these anaerobic processes as well as aerobic respiration processes. Therefore, the chemical oxygen consumption measured in killed controls appeared to result from oxidation of residual metabolites in sediment pore waters and is likely to underestimate rates under steady-state conditions.

To further investigate the existence of a residual pool of chemically oxidizable species in sediment pore waters, incubations containing $200 \mathrm{ml}$ of seawater with $4 \%$ formalin and 1 or $2 \mathrm{~cm}$ sections of sediment cores were mixed vigorously after $15 \mathrm{~h}$ of incubation to rapidly expose any reduced compounds to oxidizing conditions. Oxygen consumption was very high 14.7 and $6.2 \mathrm{mmol} \mathrm{O}_{2} \mathrm{~m}^{-2} \mathrm{~h}^{-1}$ in 1 and $2 \mathrm{~cm}$ sediments, respectively) immediately following mixing (Fig. 3). The decrease in oxygen tension in the headspace of the chambers was due to a dilution effect as well as chemical oxidation, assuming that sediment pore waters were anoxic. Taking the maximum potential dilution effect into account, we estimate that chemical oxygen consumption during the $2 \mathrm{~h}$ following mixing was at least $3.5(1 \mathrm{~cm}$ sediment $)$ and $3.7 \mathrm{mmol} \mathrm{O}_{2}$ $\mathrm{m}^{-2} \mathrm{~h}^{-1}(2 \mathrm{~cm}$ sediment).

These results indicated that the chemical oxidation of reduced compounds, such as sulfide, consumed a substantial fraction of the total oxygen uptake by estuarine sediments. Chemical oxygen consumption was 40 to $80 \%$ of the total sediment oxygen consumption in the study areas (Table 3). Measurements of chemical oxygen consumption were not made during August 1988 because anaerobic controls were used instead of formalin-killed controls to investigate the linkage between nitrification and denitrification. Dale (1978) reported

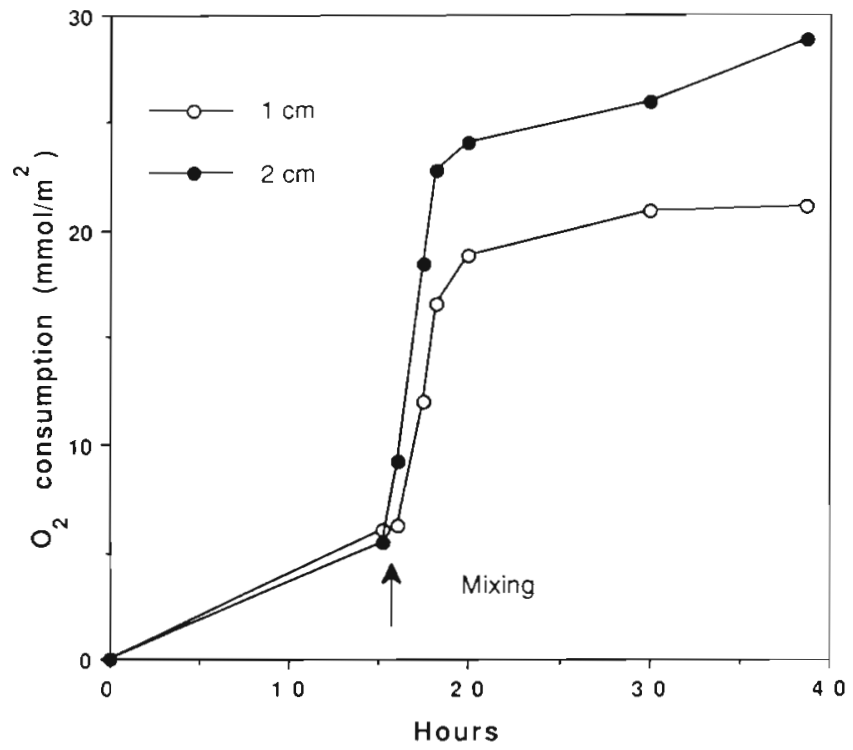

Fig. 3. Oxygen consumption by formalin-killed sediments. Sections of sediment cores were incubated for $15 \mathrm{~h}$ in $200 \mathrm{ml}$ of a $4 \%$ formalin solution prior to vigorous mixing

that chemical oxygen consumption was 61 to $77 \%$ of total oxygen consumption in coastal marine sediments of western Norway, and Hargrave (1972) also observed that 10 to $65 \%$ of total oxygen consumption was due to chemical oxygen consumption in lake sediments.

\section{Temporal variability}

Temporal variations in rates of denitrification and total oxygen consumption appeared to be dominated by temperature. The average denitrification rate in Nueces Estuary (the average of all stations) was about 6 times higher in the summer and 3 times higher in the spring than in the winter (Table 4). In Guadalupe Estuary, the average denitrification rate during the fall was similar to the average rate during the spring, but

Table 3. Percentage of total oxygen consumption as chemical oxygen consumption in formalin-killed sediments from

Nueces and Guadalupe Estuaries. nd: not determined

\begin{tabular}{|cccc|}
\hline Stn & $\begin{array}{c}\text { Chemical oxygen } \\
\text { Oct }\end{array}$ & $\begin{array}{c}\text { Maysumption } \\
\text { May of total) } \\
\text { Jan }\end{array}$ \\
\hline NA & nd & 58 & 55 \\
NC & nd & 70 & 40 \\
ND & nd & 40 & 53 \\
& & & \\
GA & 47 & 63 & 64 \\
GB & nd & 80 & 73 \\
GC & 68 & 46 & 64 \\
\hline
\end{tabular}


Table 4. Temporal variations in rates of denitrification and oxygen consumption in Nueces and Guadalupe Estuaries. Mean values of all stations are shown

\begin{tabular}{|lcccc|}
\hline Location & Month & $\begin{array}{c}\text { Temp. } \\
\left({ }^{\circ} \mathrm{C}\right)\end{array}$ & $\begin{array}{c}\text { Denitrification } \\
\left(\mu \mathrm{mol} \mathrm{N} \mathrm{m}^{-2} \mathrm{~h}^{-1}\right)\end{array}$ & $\begin{array}{c}\text { Oxygen consumption } \\
\left(\mu \mathrm{mol} \mathrm{O} \mathrm{m}^{-2} \mathrm{~h}^{-1}\right)\end{array}$ \\
\hline Nueces & Aug & 30 & 54.7 & 432 \\
Estuary & Jan & 16 & 9.0 & 198 \\
& May & 23 & 29.2 & 261 \\
Guadalupe & Oct & 24 & 23.2 & 483 \\
Estuary & Jan & 16 & 14.2 & 234 \\
& May & 23 & 23.3 & 465 \\
\hline
\end{tabular}

nitrite exhibited a similar pattern. There were no measurable fluxes of nitrate plus nitrite in the lower estuary stations (Stns ND and GC) for both estuaries. The flux of $\mathrm{N}_{2}$ (from denitrification) accounted for 52 to $67 \%$ of the total inorganic $\mathrm{N}$ flux $\left[\mathrm{N}_{2}+\mathrm{NH}_{4}^{+}+\left(\mathrm{NO}_{3}^{-}+\mathrm{NO}_{2}^{-}\right)\right]$in Nueces Estuary in May 1989 and 29 to $80 \%$ of the $\mathrm{N}$ flux in Guadalupe Estuary in October 1988 and May 1989.

\section{Nitrification rates}

was 1.6-fold higher than during the winter. In Nueces Estuary, the total oxygen consumption rate the average of all stations) was 2.5-and 1.3-fold higher during the summer and the spring, respectively, than during the winter. In Guadalupe Estuary, the average total oxygen consumption rate during the fall was similar to that during spring, but about 2 -fold higher than that during the winter.

\section{Fluxes of ammonium, nitrate and nitrite}

Ammonium fluxes from sediment cores ranged from 8.4 to $101.5 \mu \mathrm{g}$-at. $\mathrm{N} \mathrm{m}^{-2} \mathrm{~h}^{-1}$ in the study areas during the fall and the spring (Table 5). This flux range is somewhat lower than fluxes we observed during shortterm ( $2 \mathrm{~h}$ ) in situ benthic chamber experiments (30.8 to $459.2 \mu \mathrm{g}$-at. $\mathrm{N} \mathrm{m}^{-2} \mathrm{~d}^{-1}$ ) in the summer (Benner \& Yoon 1989). The ammonium flux was highest in the upper estuary and decreased with distance from the river mouth in both Nueces and Guadalupe Estuaries during the spring (Table 5). The flux of nitrate plus
Nitrification rates in sediments were estimated from denitrification rates and the fluxes of nitrate plus nitrite by assuming that nitrate which was either consumed during denitrification or accumulated in the aqueous phase of incubations was continuously provided by nitrification in the sediments. The above assumption seems reasonable because nitrate did not accumulate in chambers containing water and no sediments Likewise, several other investigators have concluded that nitrification in sediments serves as the major source of nitrate for denitrification (Jenkins \& Kemp 1984, Gardner et al. 1987, Seitzinger 1987). In the present study, the calculated nitrification rates during the fall in sediments from Guadalupe Estuary ranged from 48.9 to $78.1 \mu \mathrm{g}$-at. $\mathrm{N} \mathrm{m}^{-2} \mathrm{~h}^{-1}$. During the spring nitrification rates ranged from 40.5 to $79.4 \mu \mathrm{g}$-at. $\mathrm{N} \mathrm{m}^{-2} \mathrm{~h}^{-1}$ in Guadalupe Estuary and 17.2 to $140.2 \mu \mathrm{g}$-at. $\mathrm{N} \mathrm{m}^{-2}$ $\mathrm{h}^{-1}$ in Nueces Estuary (Table 5 ). The spatial variation of nitrification activity was very large in Nueces Estuary. The nitrification rate at the upper estuary station (Stn NA) was about 8-fold higher than at the lower station (Stn ND) of Nueces Estuary. There was, how-

Table 5. Benthic fluxes of ammonium, nitrite + nitate, dinitrogen gas, and the calculated nitrification rates in sediments of Nueces (N) and Guadalupe (G) Estuaries. The percentages shown in parentheses represent the fraction of total $N$ flux from sediments. nd: not determined; bd: below detection

\begin{tabular}{|c|c|c|c|c|c|c|}
\hline \multirow[t]{2}{*}{ Date } & \multirow[t]{2}{*}{$\operatorname{Stn}$} & \multicolumn{5}{|c|}{ Flux ( $\mu$ g-at. $\mathrm{N} \mathrm{m}^{-2} \mathrm{~h}^{-1}$ ) } \\
\hline & & $\mathrm{NH}_{4}{ }^{*}$ & $\mathrm{NO}_{3}^{-}+\mathrm{NO}_{2}^{-}$ & $\mathrm{N}_{2}$ & Total N flux & $\begin{array}{c}\text { Calculated } \\
\text { nitrification }\end{array}$ \\
\hline \multirow[t]{3}{*}{ Oct 1988} & $\mathrm{GA}$ & $56.6(42 \%)$ & $17.5(13 \%)$ & $60.6(45 \%)$ & 134.7 & 78.1 \\
\hline & $\mathrm{GB}$ & 101.5 & 0.4 & nd & nd & nd \\
\hline & $\mathrm{GC}$ & $47.8(49 \%)$ & $15.3(16 \%)$ & $33.6(35 \%)$ & 96.7 & 48.9 \\
\hline \multirow[t]{6}{*}{ May 1989} & NA & $98.2(41 \%)$ & $17.2(7 \%)$ & $123.0(52 \%)$ & 238.4 & 140.2 \\
\hline & $\mathrm{NC}$ & $16.6(31 \%)$ & $1.4(3 \%)$ & $35.2(66 \%)$ & 53.2 & 36.6 \\
\hline & ND & $8.4(33 \%)$ & bd & $17.2(67 \%)$ & 25.6 & 17.2 \\
\hline & GA & $58.7 \quad(59 \%)$ & $12.1(12 \%)$ & $28.4(29 \%)$ & 99.2 & 40.5 \\
\hline & $\mathrm{GB}$ & $43.7(36 \%)$ & $10.0(8 \%)$ & $69.4(56 \%)$ & 123.1 & 79.4 \\
\hline & GC & $10.8(20 \%)$ & bd & $42.2(80 \%)$ & 563.0 & 42.2 \\
\hline
\end{tabular}




\section{DISCUSSION}

A variety of methods have been used to estimate rates of denitrification in natural systems. We chose the direct measurement of $\mathrm{N}_{2}$ production in sealed incubation chambers because this method avoids potential problems with inhibitors and does not alter ambient concentrations of oxygen and nitrate (Seitzinger 1988). There are, however, 2 potential disadvantages of this method: (1) relatively long incubation periods are required; (2) susceptibility to contamination by atmospheric $\mathrm{N}_{2}$ during incubation and sampling. We observed that in most incubations the fluxes of dinitrogen gas, ammonium, nitrate and nitrite remained fairly constant over the course of incubations (24 d) indicating that rates of denitrification, ammonification and nitrification were not changing dramatically. Likewise, Seitzinger (1988) also observed that nutrient fluxes remained fairly constant for the duration of incubations.

The potential for contamination with atmospheric $\mathrm{N}_{2}$ is high during the incubation and sampling procedure, but with careful techniques we found that contamination during sampling was avoidable. As observed by Seitzinger et al.(1980), we found that most pore-water $\mathrm{N}_{2}$ was released from sediment cores during the first $9 \mathrm{~d}$ of incubation, indicating that denitrification measurements should be made after this period. In the present study various types of controls were used to monitor for atmospheric $\mathrm{N}_{2}$ contamination during incubation. We found that contamination with atmospheric $\mathrm{N}_{2}$ was significant using our incubation chambers and procedures, but contamination was fairly constant among chambers and incubation conditions. Therefore, all data presented herein for denitrification rates were corrected for atmospheric $\mathrm{N}_{2}$ contamination during incubation.

Another important advantage of having killed controls is that biological and chemical oxygen consumption can be differentiated. There are, however, several potential problems with the use of poisons to differentiate these processes (Dale 1978). Anaerobic biological processes are responsible for ultimately producing most of the observed chemical oxygen demand, and these processes are terminated along with aerobic respiration. Thus, the use of poisons could result in underestimatation of chemical oxygen consumption. Reduced compounds resulting from anaerobic processes, such as sulfide, are susceptible to both biological and chemical oxidation. These compounds may be more susceptible to chemical oxidation in the absence of biological activity leading to overestimation of chemical oxidation. Given these caveats, we estimate that chemical oxygen consumption was of the same magnitude as biological oxygen consumption. Moreover, about half of the biological oxygen consumption was due to nitrification rather than the oxidation of organic matter. These results have important implications for using oxygen consumption as a measure of aerobic carbon mineralization in estuaries, and are in general agreement with recent studies (Mackin \& Swider 1989, Sampou \& Oviatt 1991) indicating that aerobic respiration accounts for a relatively small fraction of the total carbon mineralization in coastal marine sediments.

Denitrification rates reported for marine coastal areas range from 0 to $888 \mu \mathrm{mol} \mathrm{N} \mathrm{m}^{-2} \mathrm{~h}^{-1}$ (see review by Seitzinger 1988). Direct measurements of $\mathrm{N}_{2}$ evolution from sediments, as was done in the present study, have been reported for 2 other estuaries. Rates of $\mathrm{N}_{2}$ production in Ochlockonee Bay, Florida, ranged from 10 to $115 \mu \mathrm{mol} \mathrm{N} \mathrm{m}^{-2} \mathrm{~h}^{-1}$ (Seitzinger 1987), and rates in Narragansett Bay, Rhode Island, ranged from 0 to $210 \mu \mathrm{mol} \mathrm{N} \mathrm{m}{ }^{-2} \mathrm{~h}^{-1}$ (Seitzinger et al. 1984). Denitrification rates in Nueces and Guadalupe Estuaries (4 to 71. $\mu \mathrm{mol} \mathrm{N} \mathrm{m}^{-2} \mathrm{~h}^{-1}$ ) were slightly lower than rates in Ochlockonee and Narragansett Bays.

Sulfate reduction is typically the predominant process responsible for the mineralization of organic carbon in anaerobic marine sediments (Jørgensen 1982) and accounts for about $50 \%$ of the total mineralization of organic matter in shallow coastal sediments (Jørgensen 1977). In the present study the relatively high percentages of total oxygen consumption that were accounted for as chemical oxygen consumption are suggestive that anaerobic metabolism (sulfate reductionj was a major pathway of carbon mineralization. Denitrification is generally considered to be of minor quantitative significance for carbon mineralization compared to aerobic respiration and sulfate reduction. Sørensen et al. (1979) reported that carbon mineralization due to denitrification was only $0.05 \%$ of that by aerobic respiration and $0.17 \%$ of that by sulfate reduction in relatively oxidizing, sandy, coastal sediments. However, in estuarine sediments we estimated that carbon mineralization by denitrifying bacteria ranged from 40 to $179 \%$ of that by aerobic heterotrophs. These estimates are based on the observation that most ( ca $75 \%$ ) of the total oxygen consumption in sediments of Nueces and Guadalupe Estuaries was due to chemical oxidation and nitrification.

Significant spatial differences in denitrification and oxygen consumption rates were observed in both Nueces and Guadalupe Estuaries. Spatial differences were more pronounced in Nueces Estuary, but in both estuaries rates of denitrification and oxygen consumption were highest in the upper estuary. Two characteristics of the sediments in these estuaries, water content (porosity) and organic matter content, appear to positively influence denitrification and oxygen consumption rates. The porosity of sediments can influence these processes by affecting the rates of diffusion of $\mathrm{O}_{2}$ 
into sediments. Higher rates of $\mathrm{O}_{2}$ diffusion into surface sediments may indirectly stimulate denitrification, which itself is inhibited by $\mathrm{O}_{2}$, by enhancing rates of nitrification (Grundmanis \& Murray 1977). Most of the nitrate used by denitrifiers is supplied by nitrification in sediments (Jenkins \& Kemp 1984, Gardner et al. 1987, Seitzinger 1987). In the present study we observed that the incubation of sediment cores under anoxic conditions completely inhibited rates of denitrification, indicating that nitrification and denitrification were tightly linked processes.

In Nueces Estuary, the highest denitrification rates were observed in the upper estuary where the porosity of sediments was relatively high, whereas the lowest denitrification rates were generally observed in the lower estuary where the porosify of sediment was relatively low. The organic matter content of sediments, which serves as the carbon and energy source for aerobic heterotrophs and denitrifiers, was also typically higher in the upper estuaries where rates of oxygen consumption and denitrification were highest.

Strong seasonal variations in denitrification and oxygen consumption rates were also observed in Nueces and Guadalupe Estuaries. Spring and summer denitrification rates were 2 - to 6-fold higher than winter rates, and spring and summer oxygen consumption rates were about 2.5 -fold higher than winter rates. Seitzinger et al. (1984) observed no marked seasonal variation in denitrification rates for Narragansett Bay. Jørgensen (1989) reported that the peak of denitrification rates in Norsminde Fjord was observed during the spring and the highest rate was related to the degradation of benthic phytoplankton right after spring blooming. Seitzinger (1987) also observed that the highest denitrification rates in Ochlockonee Bay, Florida, occurred during the late spring.

A partial budget of the sources and sinks of $N$ in Nueces and Guadalupe Estuaries is presented in Table 8. The amount of $N$ removed from the Guadalupe Estuary by denitrification was equivalent to about $38 \%$ of the total $\mathrm{N}$ inputs and $57 \%$ of the dissolved inorganic nitrogen (DIN) entering the estuary from riverine inflow and precipitation. In a recent review of data for 6 estuaries with widely varying $N$ input rates, Seitzinger (1988) found that denitrification removed an amount of $\mathrm{N}$ equivalent to about 40 to $50 \%$ of the DIN inputs

In Nueces Estuary, the riverine and precipitation inputs of DIN were much lower $(\sim 10$-fold $)$ than the $\mathrm{N}$ removed by denitrification, indicating that major additional $N$ sources are required. Nitrogen fixation may supply some portion of the $\mathrm{N}$ required in the system, but fixation generally accounts for only a minor percentage of $\mathrm{N}$ inputs to estuaries (Howarth et al. 1988). Anthropogenic $N$ inputs from municipalities and industries are likely to be major sources of $\mathrm{N}$ in Nueces Estuary. Unfortunately, many point source effluents are not monitored for DIN or DON. Oppenheimer et al. (1975) estimated that point source effluents, as well as urban and agricultural runoff, provided approximately $181 \mathrm{~kg}$-at. $\mathrm{N} \mathrm{d}^{-1}$. The current anthropogenic $\mathrm{N}$ input into the estuary is probably much higher considering the industrial and municipal growth in the area during the past 15 yr. It appears that anthropogenic inputs are the major $\mathrm{N}$ source to the estuary.

Acknowledgements. We thank Paul Montagna and Rick Kalke for SCUBA collection of sediment cores and water samples. We thank Terry Whitledge and George Jackson for helpful discussions about this research. Wayne Gardner and an anonymous reviewer also provided helpful suggestions. This work was supported by the Water Research and Planning Fund, and administered by the Texas Water Development Board under contract number 9-483-706. This is contribution 842 of the University of Texas Marine Science Institute

\section{LITERATURE CITED}

Benner, R., Yoon, W. B. (1989). Nitrogen cycling and bacterial production in Nueces and Guadalupe Estuaries. Techn. Report No. TR/89-001 to the Texas Water Development Board, Austin 
Cooper, A. B. (1984). Activities of benthic nitrifiers in streams and their role in oxygen consumption. Microb. Ecol. 10 $317-334$

Dale, T (1978). Total chemical and biological oxygen consumption of the sediments in Lindasspollene. Western Norway. Mar. Biol. 49: 333-341

Deegan, L. A.. Day, J. W. Gosselink, J. G., Yanez-Arancibia, A. Chavez, G. S., Sanchez-Gil, P. (1986). Relationships among physical characteristics, vegetation distribution and fisheries yield in Gulf of Mexico estuaries. In: Wolfe, D. A. (ed.) Estuarine variability. Academic Press, Orlando, p. 83-100

Gardner, W. S., Nalepa, T F., Malczyk, J. M. (1987). Nitrogen mineralization and denitrification in Lake Michigan sediments. Limnol. Oceanogr. 32: 1226-1238

Gottschalk, G. (1979). Bacterial metabolism. Springer-Verlag, New York, p. 101-103

Grundmanis, V. G., Murray, J. W. (1977). Nitrification and denitrification in marine sediments from Puget Sound. Limnol. Oceanogr. 22: 804-813

Hargrave, B. T. (1972). Oxidation-reduction potentials, oxygen concentration and oxygen uptake of profundal sediments in a eutrophic lake. Oikos 23: 167-177

Howarth, R. W., Marino, R., Lane, J., Cole, J. J. (1988). Nitrogen fixation in freshwater, estuarine, and marine ecosystems. 1. Rates and importance. Limnol. Oceanogr 33: $669-687$

Jenkins, M. C., Kemp, W. M. (1984). The coupling of nitrification and denitrification in two estuarine sediments. Limnol. Oceanogr. 29: 609-619

Jørgensen, B. B. (1977). The sulfur cycle of a coastal marine sediment (Limfjorden, Denmark). Limnol. Oceanogr 22 $814-832$

Jorgensen, B. B. (1982). Mineralization of organic matter in the sea bed - the role of sulphate reduction. Nature 296 $648-645$

Jørgensen, K. S. (1989). Annual pattern of denitrification and nitrate ammonification in estuarine sediment. Appl. environ. Microbiol. 55: 1841-1847

Jørgensen, K. S., Sørensen, J. (1988). Two annual maxima of nitrate reduction and denitrification in estuarine sediment (Norsminde Fjord, Denmark). Mar. Ecol. Prog. Ser. 48 $147-154$

Mackin, J. E., Swider, K. T (1989). Organic matter decomposition pathways and oxygen consumption in coastal marine sediments. J. mar. Res. 47:681-716

Nixon, S. (1981). Remineralization and nutrient cycling in coastal marine ecosystems. In: Neilson, B. J., Cronin, L. E (eds.) Estuaries and nutrients. Humana Press, Clifton, NJ, p. $111-138$

This article was presented by S. Y. Newell, Sapelo Island, Georgia, USA
Oppenheimer, C. H., Isensee, T., Brogden, W. B., Bowman, D. (1975). Establishment of operational guidelınes for Texas coastal zone management. Biological uses criteria. Final Rep. to the National Science Foundation /Grant \#Gl-348770X) and Office of the Governor of Texas (IAC \#74-75-0685), Univ. Texas at Austin, Mar. Sci. Inst., p. 85

Sampou, P., Oviatt, C. A. (1991). A carbon budget for a eutrophic marine ecosystem and the role of sulfur metabolism in sedimentary carbon, oxygen and energy dynamics. J mar. Res. 49: 825-844

Seitzinger, S. (1987). Nitrogen biogeochemistry in an unpolluted estuary: the importance of benthic denitrification. Mar. Ecol. Prog. Ser. 37: 65-73

Seitzinger, S. (1988). Denitrification in freshwater and coastal marine ecosystems: ecological and geochemical significance. Limnol. Oceanogr. 33: 702-724

Seitzinger, S., Nixon, S., Pilson, M. E. Q. (1984). Denitrification and nitrous oxide production in a coastal marine ecosystem. Limnol. Oceanogr. 29: 73-83

Seitzinger, S., Nixon, S., Pilson, M. E. Q., Burke, S. (1980). Denitrification and $\mathrm{N}_{2} \mathrm{O}$ production in near-shore marine sediments. Geochim. cosmochim. Acta 44: 1863-1860

Smith, C. J., DeLaune, R. D., Patrick, W. H. Jr (1985). Fate of riverine nitrate entering an estuary: 1 Denitrification and nitrogen burial. Estuaries 8: 15-21

Solorzano, L. (1969). Determination of ammonium in natural waters by the phenolhypochlorite method. Limnol. Oceanogr 14: 799-801

Sørensen, J., Jørgensen, B. B., Revsbech, N. P. (1979). A comparison of oxygen, nitrate, and sulphate respiration in coastal marine sediments. Microb. Ecol. 5: 105-115

Strickland, J. D., Parsons, T R. (1972). A practical handbook of seawater analysis, 2nd edn. Bull. Fish. Res. Bd Can. 167: $1-311$

TDWR (Texas Department of Water Resources) (1980). Guadalupe Estuary: a study of the influence of freshwater inflows. Final Rep. \#LP-107. Texas Dept Water Res., Austin

TDWR (Texas Department of Water Resources) (1981). Nueces and Mission-Aransas Estuaries: a study of the influence of freshwater inflows. Final Rep. \#LP-108, Texas Dept Water Res., Austin

Whitledge, T E. (1989). Nutrient distributions and dynamics in Lavaca, San Antonio and Nueces/Corpus Christi Bays in relation to freshwater inflow, Part I, Results and discussion. Trch. Rep. No. TR/89-007 to the Texas Water Development Board, Austin

Manuscript furst received: July 7, 1992

Revised version accepted: November 3, 1992 